\title{
Biolegalidade, imaginário forense e investigação criminal
}

Biolegality, the Forensic Imaginary and Criminal Investigation

Bio-légalité, imaginaire criminalistique et investigation criminelle

Helena Machado e Susana Costa

\section{OpenEdition}

\section{Journals}

Edição electrónica

URL: http://journals.openedition.org/rccs/4927

DOI: $10.4000 /$ rccs. 4927

ISSN: $2182-7435$

\section{Editora}

Centro de Estudos Sociais da Universidade de Coimbra

Edição impressa

Data de publição: 1 Junho 2012

Paginação: 61-84

ISSN: 0254-1106

\section{Refêrencia eletrónica}

Helena Machado e Susana Costa, "Biolegalidade, imaginário forense e investigação criminal », Revista Crítica de Ciências Sociais [Online], 97 | 2012, colocado online no dia 19 abril 2013, criado a 30 abril 2019. URL : http://journals.openedition.org/rccs/4927 ; DOI : 10.4000/rccs.4927 


\section{HELENA MACHADO SUSANA COSTA}

\section{Biolegalidade, imaginário forense e investigação criminal*}

Neste texto discutimos alguns contornos das configurações locais das representações e usos sociais da tecnologia de DNA na investigação criminal em Portugal. A abordagem da rede sociotécnica que alinha a ciência forense com políticas de governação estatal, as leis e as práticas de investigação criminal e os imaginários culturais em torno do DNA e do trabalho de investigação criminal é realizada a partir dos conceitos de biolegalidade e de imaginário forense, por sua vez ancorados, respetivamente, nas noções de biocidadania e de bioidentificação. Adotou-se uma perspetiva teórico-metodológica de tipo interpretativo e qualitativo fundamentada em análise de legislação e na compreensão de sentidos e significados atribuídos à utilização de tecnologia de DNA da parte de elementos da Polícia Judiciária. O nosso objetivo é discutir algumas modalidades de tensões locais criadas por processos de exportação da tecnologia de DNA, que têm a sua origem em sociedades e culturas com diferentes histórias de governação de tecnologia, de regulação das práticas de investigação criminal e de produção de prova em tribunal.

Palavras-chave: bases de dados; biolegalidade; imaginário forense; investigação criminal; tecnologia de DNA.

\section{Introdução}

O trabalho policial de investigação criminal e a criação e a expansão de bases de dados genéticos com finalidades forenses assentam numa rede sociotécnica que alinha a ciência forense com políticas de governação estatal, leis e práticas de investigação criminal, alimentando imaginários culturais que conjugam, simultaneamente, a crença na infalibilidade da identificação de

\footnotetext{
* Este artigo baseia-se em investigação apoiada pela Fundação para a Ciência e a Tecnologia (Ministério da Ciência, Tecnologia e Ensino Superior) e desenvolvida no Centro de Estudos Sociais da Universidade de Coimbra no âmbito dos seguintes projetos: "Base de dados de perfis de ADN com propósitos forenses - questões atuais de âmbito ético, prático e político” (FCOMP-01-0124-FEDER-009231) coordenado por Helena Machado; Bolsa de pós-doutoramento de Susana Costa, "O ADN e a investigação criminal - uma análise sociológica comparativa da sua evolução e impactos em Portugal e no Reino Unido” (SFRH/BPD/63806/2009).
} 
criminosos pela tecnologia de DNA, ${ }^{1}$ com a promessa do combate eficaz do crime. Trata-se de uma coprodução da justiça criminal e da tecnociência - um 'idioma' (Jasanoff, 2004) - que produz "centros de cálculo" (Latour, 1987) com efeitos tanto nas práticas dos atores do sistema de justiça - tribunais, polícias e peritos forenses - como na governamentalidade dos corpos e nas identidades daqueles que são alvo de captura, classificação, armazenamento e gestão de informação (Machado et al., 2010).

No âmbito deste texto elaboramos uma reflexão em torno de alguns contornos e configurações locais criados pela utilização da tecnologia de DNA na investigação criminal em Portugal, partindo de uma análise da legislação que criou e regula o funcionamento de uma base de dados de perfis de DNA com finalidades forenses e que estabelece os princípios de organização da investigação criminal e da compreensão e interpretação de sentidos e significados atribuídos por agentes da Polícia Judiciária à utilização da tecnologia de DNA nas práticas de investigação criminal em Portugal. Numa primeira parte, apresentamos uma síntese da discussão teórica sobre a relação entre a justiça criminal e a biotecnologia a partir dos conceitos de biolegalidade e de "imaginário forense", por sua vez, e respetivamente, assentes nas ideias de biocidadania e bioidentificação. Numa segunda parte, discutimos alguns contornos das configurações locais criadas pela utilização da tecnologia de DNA na investigação criminal em Portugal. Com base em análise de legislação e em entrevistas realizadas junto de elementos da Polícia Judiciária, ${ }^{2}$ analisamos algumas tensões locais criadas por processos de exportação da tecnologia de DNA para sociedades e culturas com histórias diferenciadas de governação de tecnologia e de regulação das práticas de investigação criminal e de produção de prova em tribunal. Argumentamos ainda que as contingências associadas à utilização da tecnologia de DNA na investigação criminal em Portugal podem produzir impactos na confiança pública em torno do sistema de justiça criminal.

\footnotetext{
${ }^{1}$ O DNA (Deoxyribonucleic acid) é a molécula em que se encontram codificadas as características genéticas de cada pessoa. Por vezes, em textos em português, usa-se a formulação ADN (correspondente a ácido desoxirribonucleico), que é uma tradução da sigla DNA. Contudo, usaremos a sua designação em inglês, ou seja, DNA, por ser a designação aprovada pela Sociedade Internacional de Bioquímica.

2 As entrevistas resultam do trabalho de investigação em curso, conduzido por Susana Costa, junto de atores dos diferentes órgãos de polícia criminal nacionais. Os entrevistados foram selecionados de acordo com um critério fundamental: todos os potenciais participantes teriam experiências prévias de índole profissional que lhes conferiam um nível especial de conhecimentos de terreno no âmbito da investigação criminal em Portugal. No âmbito do presente artigo, centrar-nos-emos num conjunto de seis entrevistas realizadas em 2011 a elementos da Polícia Judiciária.
} 


\section{Biolegalidade e imaginário forense}

O conceito de biolegalidade, proposto por Lynch e Mcnally (2009) para se referirem à coprodução da biotecnologia e de legislação no contexto da justiça criminal, comporta dois elementos principais: por um lado, remete para as interações entre a esfera do direito e a esfera da ciência, das quais resultam efeitos de adequação da genética às necessidades e constrangimentos do sistema jurídico-legal. Por outro lado, expande a discussão sobre formas de biocidadania, ao alargar a discussão das novas configurações de identidade e cidadania ao campo da aplicação da genética na investigação criminal, ou seja, às identidades suspeitas relacionadas com indivíduos ou grupos identificados como tendo um risco elevado de cometer crimes, e que deverão ser vigiados e investigados.

O debate teórico em torno da biocidadania tem-se centrado em modos emergentes de cidadania ancorados em conceções de saúde e de biologia (Rose, 2007) e uma das temáticas mais debatidas diz respeito à transformação dos corpos e das identidades por intermédio de aplicações tecnológicas e conhecimentos médicos. As aplicações de novas tecnologias genéticas constroem novas identidades individuais e coletivas - "identidades técnico-científicas" (Rabinow, 2008) - que estão "a gerar novas biossocialidades, entendidas como novos modos de relações sociais profundamente ligados a essas identidades" (Clarke et al., 2009: 23). Literatura recente sobre as novas identidades e novas formas de cidadania que emergem da aplicação de tecnologias genéticas tem-se centrado predominantemente nas identidades médicas associadas a indivíduos/grupos de risco, saudáveis e doentes, e nas identidades cívicas baseadas em movimentos sociais de defesa do direito de pacientes e famílias com problemas de índole médica e genética (Akrich et al., 2008; Atkinson et al., 2007; Gibbon e Novas, 2008).

A biolegalidade alarga a discussão teórica e a aplicação empírica da ideia de biocidadania aos contextos de políticas governamentais de combate e dissuasão do crime pela apertada vigilância sobre corpos suspeitos - aquilo a que podemos chamar os "suspeitos genéticos" (Hindmarsch e Prainsack, 2010). Neste sentido, e socorrendo-nos das palavras de Lynch e McNally “[em] vez de produzir uma identidade médica de 'risco', a biolegalidade produz 'suspeitos de risco', 'pré-suspeitos' e 'suspeitos estatísticos'” (Lynch e McNally, 2009: 284). As identidades suspeitas resultam, assim, tanto das práticas de investigação criminal como da perícia genética no âmbito do desenvolvimento e utilização de bases de dados de perfis de DNA para efeitos forenses. Mas são também construídas pelos próprios sujeitos que são alvo de recolha de amostra biológica e cujos perfis são inseridos em sistemas tecnológicos de informatização e sistematização de informação 
genética cada vez mais complexos, que pode ser cruzada com outro tipo de informação com interesse policial (biografia relativa a "carreira criminal", registo criminal, impressões digitais, fotografias, etc.) (Prainsack e Kitzberger, 2009 e Machado et al., 2011a).

A identificação conferida pelo perfil de DNA produz a ilusão da certeza, a exclusão da dúvida e a perceção da infalibilidade da tecnologia, minimizando as eventuais ambiguidades e praticamente eliminando as possibilidades de dúvida e incertezas (Aas, 2006: 150), constituindo-se como elementos-chave que alimentam o chamado "imaginário forense" que está associado à construção de bases de dados de perfis de DNA.

De acordo com Williams (2010), este imaginário forense conjuga duas ideias centrais: que a biologia e a genética são ciências que permitem identificar com eficácia os indivíduos, tornando-se central nas práticas de análise de cena de crime - a bioidentificação; e que a crescente utilização de perfis de DNA vai melhorar a eficácia da investigação criminal e com isso prevenir e dissuadir a criminalidade.

Vários autores têm discutido o papel da bioidentificação - ou identificação pelo corpo, englobando a identificação por perfis de DNA, mas também a dactiloscopia (identificação por impressões digitais) ou a antropometria (identificação por medidas físicas do corpo humano) já usadas no século XIX em vários países do mundo (Cole, 2002), inclusive em Portugal - como um elemento integrante do desenvolvimento do aparelho de Estado moderno (Cole e Lynch, 2006; Garland, 2001; Lyon, 2001). Deste modo, a trajetória criminal torna-se visível para o Estado e os corpos potencialmente perigosos tornam-se mais suscetíveis de serem controlados: cria-se uma ligação entre determinado corpo (único, identificado e individualizado) e um arquivo estatal (bases de dados de registos criminais, de impressões digitais e, mais recentemente, bases de dados de perfis de DNA). Trata-se de uma "ligação credível", tanto para cientistas, burocratas e atores judiciais, como para o público em geral (Cole, 2002) e que se articula com processos de legitimação política e social da cientifização do trabalho policial, articulado com a criação e a expansão de bases de dados com informação genética para efeitos de investigação criminal.

O imaginário forense representa assim aquilo a que alguns autores apelidam de imaginário da "máquina da verdade" (Lynch et al., 2008), alimentado, em boa medida, por mensagens culturais projetadas pelos média. Existe hoje abundante literatura sobre o chamado efeito CSI, numa referência à famosa série televisiva Crime Scene Investigation, cuja estrutura e lógica narrativa parece favorecer perceções públicas da ciência forense, em particular da tecnologia de DNA, como uma espécie de superciência, 
absolutamente infalível no combate ao crime. Este efeito CSI foi originariamente utilizado para avaliar as alegadas perceções distorcidas da ciência forense, que seriam construídas por jurados em julgamentos reais e que se traduziriam numa preponderância na avaliação e valoração da prova de DNA (para uma síntese do debate, ver Cole e Dioso-Villa, 2007).

Pela mistura "credível" de elementos ficcionais e elementos com sustentação nos procedimentos reais da ciência forense e da investigação criminal apoiada em tecnologias avançadas (Deutsch e Cavender, 2008; Durnal, 2010), o CSI configura uma performance cultural que cria mitos em torno do que a ciência-deveria-ser (wishful-thinking science) (Kruse, 2010: 88). É provável, então, que o público possa construir a partir destas narrativas um imaginário da ciência forense, das tecnologias de identificação por perfis de DNA e dos próprios agentes de investigação que, embora assente numa aparente verosimilhança relativamente a algumas técnicas, ignora as contingências das suas aplicações no mundo real da investigação criminal e da análise laboratorial.

No âmbito do presente texto, analisamos algumas configurações das tensões entre a biolegalidade e o imaginário forense criadas pelas circunstâncias legais e regulatórias da investigação criminal e do processo biopolítico de criação de uma base de dados de perfis de DNA com finalidades forenses. As discrepâncias entre os imaginários coletivos em torno da eficácia da tecnologia de DNA na identificação de criminosos e as realidades locais da legislação que regula o funcionamento da base de dados de perfis de DNA para identificação criminal e a estrutura organizacional da investigação do crime, das culturas judiciárias e práticas policiais nesta matéria ilustram cabalmente as tensões criadas por processos de exportação da tecnologia de DNA para sociedades e culturas que têm histórias de governação de tecnologia e modalidades de construção da confiança pública bastante distintas das sociedades e culturas de onde são originárias. Saliente-se, ainda, que a utilização da tecnologia de DNA no sistema de justiça criminal teve origem em Inglaterra e nos EUA, países com sistemas de justiça de tipo adversarial (Lazer, 2004). Assim sendo, a incorporação da prova científica de DNA em sistemas de justiça de tipo inquisitorial como o português pode suscitar complexidades adicionais, ainda insuficientemente discutidas (Toom, 2010).

\section{Investigação criminal e base de dados de perfis de DNA em Portugal}

Em países centrais que têm servido de cânone ao estabelecimento de bases de dados de perfis de DNA, como é o caso do Reino Unido e dos Estados Unidos da América, destaca-se claramente a acentuação do papel da 
cientifização e profissionalização da polícia pelos usos da genética na investigação criminal (Cole, 2002; Nuffield Council, 2007; Williams, 2003; Williams et al., 2004). Mas o mesmo já não acontece em países como Portugal, em que se conjugam diversos fatores que limitam e subordinam o trabalho de investigação policial à existência de legislação que faz depender de uma ordem de um juiz a atuação policial em matéria de recolha de amostra biológica em suspeitos de prática de crime; mas também as contingências criadas pela Lei n. ${ }^{\circ}$ 49/2008, de 27 de agosto (Lei de Organização da Investigação Criminal), que aumentam as zonas de incerteza no processo de gestão da cena de crime, a par da escassez de investimento em recursos humanos e tecnológicos ao nível do trabalho policial (Costa, 2003; Machado e Santos, 2012). Comecemos por uma breve análise dos instrumentos legais que regulam, respetivamente, a criação de uma base de dados de perfis de DNA para fins de identificação civil e criminal e a organização da investigação criminal.

Em 2004, foi estabelecido o regime jurídico das perícias médico-legais e forenses pela Lei n. ${ }^{\circ}$ 45/2004 que limita a realização das mesmas ao Instituto Nacional de Medicina Legal - instituição pública que funciona sob a supervisão direta do Ministério da Justiça - e respetivas delegações. Apenas em casos excecionais, perante manifesta impossibilidade dos serviços do INML, poderão as perícias ser realizadas por entidades terceiras, contratadas ou indicadas pelo Instituto (n. ${ }^{\circ} 2$ do artigo 2 da Lei n. ${ }^{\circ} 45 / 2004$ ). A centralidade do Instituto Nacional de Medicina Legal na realização de perícias forenses é reforçada em 2008, pela Lei n. ${ }^{\circ}$ 5/2008, que criou uma base de dados de perfis de DNA para finalidades de identificação civil e criminal: a entidade responsável pela base de dados e por todas as suas operações é o Instituto Nacional de Medicina Legal (n. ${ }^{\circ} 1$ do artigo $16 .{ }^{\circ}$, Lei n. ${ }^{\circ}$ 5/2008).

A Lei n. ${ }^{\circ}$ 5/2008 apresenta um conjunto de disposições que confere controlo e poder de decisão aos juízes na construção das bases de dados de DNA, os quais são os responsáveis por ordenar a recolha de amostra (n. ${ }^{\circ} 2$ do artigo $8 .^{\circ}$, Lei n. $^{\circ}$ 5/2008) e a inserção de perfis (n. ${ }^{\circ} 3$ do artigo $18 .^{\circ}$, Lei n. ${ }^{\circ}$ 5/2008). A tradição dos sistemas inquisitoriais ${ }^{3}$ pesou nas opções

\footnotetext{
${ }^{3} \mathrm{Na}$ tradição inquisitorial o juiz tem um papel predominante na condução do julgamento e na apreciação da prova, protagonizando os interrogatórios e decidindo quais são as provas aceites em julgamento. A diferença fundamental é que enquanto num sistema adversarial há lugar a um confronto entre duas versões dos factos com a finalidade de resolução do litígio, no sistema inquisitorial a função do tribunal é "apurar a verdade" (Toom, 2010). Na conclusão deste texto desenvolvemos em pormenor as principais diferenças nos sistemas jurídicos adversarias e inquisitoriais, com o propósito de perspetivar os respetivos impactos dos distintos regimes de admissão e apreciação de prova, nomeadamente no que respeita à presença de prova de DNA nos tribunais.
} 
do legislador, de resto como acontece noutros países onde os magistrados, judiciais ou do Ministério Público, assumem papéis de maior relevância na construção das bases de dados, por exemplo, ao assumirem a responsabilidade por decisões de inserção e de remoção de perfis, como acontece na Alemanha, Bélgica, Espanha, França, Holanda, Itália, Letónia e Luxemburgo (Machado et al., 2011b).

Para além das restrições legais ao processo de recolha de amostras biológicas de indivíduos suspeitos da prática de crimes, o trabalho da polícia ao nível da investigação criminal em Portugal encontra também restrições pelo processo de comunicação do resultado da análise, da parte da entidade que detém a custódia da base de dados - o Instituto Nacional de Medicina Legal - que é feito apenas ao juiz, o qual, por sua vez, apenas comunica essa informação ao Ministério Público ou aos órgãos de investigação criminal caso entenda necessário e mediante apresentação de requerimento fundamentado (alíneas a e b do n. ${ }^{\circ} 1$ do artigo 19. ${ }^{\circ}$ da Lei n. ${ }^{\circ}$ 5/2008). O acesso da polícia à informação genética no curso de uma investigação criminal é assim bastante restrito, hierarquizado e burocratizado.

As limitações ao trabalho policial acentuam-se igualmente pelo modelo hierárquico da organização da investigação criminal, regulada pela Lei n. ${ }^{\circ} 49 / 2008$ de 27 de agosto, que embora sendo dirigido pela autoridade judiciária (n. ${ }^{\circ} 1$ do artigo $2{ }^{\circ}$, Lei no ${ }^{\circ}$ 49/2008), é coadjuvado pelos órgãos de polícia criminal: a Polícia Judiciária (PJ), ${ }^{4}$ a Polícia de Segurança Pública (PSP) e a Guarda Nacional Republicana $(\mathrm{GNR})^{5}$ (n. 2 e 3 do artigo 2. ${ }^{\circ}$, Lei n. ${ }^{\circ}$ 49/2008), sendo a PJ apoiada nas suas diligências pela Polícia Científica e a PSP pela Unidade de Polícia Técnica (UPT).

O imaginário forense da infalibilidade e eficácia da tecnologia de DNA sustenta-se em práticas e culturas judiciárias e criminais de países que não só têm expandido largamente as suas bases de dados de informação genética aplicadas na investigação e combate ao crime (pela quase ausência de restrições para a inserção e retenção de perfis), como também conferem amplos poderes à atuação da polícia no processo de recolha e análise de amostras e no acesso à informação. Por exemplo, enquanto em Portugal apenas podem ser recolhidas amostras biológicas de arguidos e de condenados por crime doloso com pena concreta de prisão igual ou superior a 3 anos e mediante despacho do juiz (artigo 8 da Lei n. ${ }^{\circ}$ 5/2008), em Inglaterra e no País de Gales a polícia pode colher amostra biológica de qualquer detido e os perfis são retidos indefinidamente.

\footnotetext{
${ }_{4}$ PJ sob a tutela do Ministério da Justiça (MJ).

5 PSP e GNR sob a tutela do Ministério da Administração Interna (MAI).
} 
As diferenças relativamente aos países que têm servido de cânone para o investimento e o desenvolvimento da aplicação da tecnologia do DNA na investigação criminal, como referido anteriormente, criam tensões locais que podem mesmo reforçar imagens de ineficiência da polícia portuguesa (Machado e Santos, 2009a; Machado e Santos, 2009b). Trata-se de comparar as atividades de investigação policial e a dimensão e as modalidades de acesso e utilização de informação genética na investigação do crime que podemos encontrar no cenário existente em Portugal - uma base de dados de informação genética ainda no seu início e com muitas restrições na sua expansão e um acesso muito limitado por parte da polícia - e a realidade encontrada, por exemplo, em Inglaterra - país que tem a base de dados de perfis de DNA mais antiga do mundo (criada em 1995) e pioneiro na aplicação da tecnologia de DNA na investigação criminal.

\section{Cientifização do trabalho policial e contingências locais}

A legitimação do trabalho policial de investigação criminal tem decorrido, em boa medida, daquilo que se poderá designar cientifização do trabalho policial, apoiado na crescente aplicação de tecnologia no processo de circunscrição da cena de crime e de recolha e análise de vestígios e conjugado com um dos alicerces do "imaginário forense": a invocação da necessidade de utilização de tecnologias avançadas para aumentar a eficácia e rapidez da investigação criminal (Lynch et al., 2008; Williams e Johnson, 2008).

Uma parte substancial das tecnologias que apoiam esse trabalho policial assenta no desenvolvimento e expansão de modernos sistemas de identificação humana e classificação de indivíduos com base em características biológicas, como é o caso de bases de dados de impressões digitais e perfis de DNA. Como afirmam Caplan e Torpey, a história da investigação criminal tem sido marcada por "sucessivos esforços para racionalizar e estandardizar práticas de identificação e os sistemas de armazenamento e pesquisa da crescente documentação gerada" (2001: 9).

No conjunto de recursos tecnológicos aplicados à investigação criminal destaca-se, hoje em dia, a recolha de vestígios de cenas de crime ou a recolha de amostra biológica a suspeitos ou arguidos, que podem ser comparadas com material biológico ou perfis genéticos previamente existentes em arquivos policiais ou em bases de dados forenses, estas últimas em amplo crescimento um pouco por todo o mundo (Hindmarsh e Prainsack, 2010). O trabalho policial de investigação criminal apoiado na tecnologia de DNA ilustra de que forma a tecnologia pode ser uma força centrípeta que conjuga, organiza e mantém unido um conjunto diversificado de elementos sociais, políticos, tecnológicos, humanos e não humanos (Latour, 1987), formando 
aquilo que Michel Callon designou por "ator-rede" (actor network), para descrever um conjunto de elementos heterogéneos associados por meio de uma rede tecnológica, mas que "podem a qualquer momento redefinir a sua identidade e relações mútuas de uma forma nova e trazer novos elementos para a rede" (Callon, 1987: 93).

Aplicando esta ideia aos usos da tecnologia de DNA na investigação criminal, pode-se afirmar que do lado dos atores sociais humanos temos investigadores criminais, peritos forenses, os autores de crime e os tribunais; e no conjunto de atores não-humanos podemos incluir a tecnologia de identificação por DNA, outras tecnologias usadas na criminalística, tais como a lofoscopia, a dactiloscopia ou a balística. Pode-se ainda englobar nos atores sociais não-humanos todo o conjunto de objetos e de vestígios deixados na cena de crime, ${ }^{6}$ as chamadas "testemunhas silenciosas" ou "testemunhas mudas" do ato criminoso, pelas quais o autor inadvertidamente pode deixar rasto potencialmente incriminatório (pegadas, dedadas, fibras de tecido, cabelo, sangue, sémen, etc.).

Neste contexto, analisaremos nas próximas secções as representações sobre o papel da tecnologia do DNA e dos constrangimentos ao trabalho policial que decorrem, de acordo com atores entrevistados, do desfasamento entre as tensões criadas pelo imaginário forense - a ideia, amplamente disseminada, quer pelos média, quer pelo poder político e algumas franjas da comunidade de peritos forenses, de que a crescente utilização de perfis de DNA vai melhorar a eficácia da investigação criminal - e os constrangimentos criados localmente, tanto no terreno (pela gestão da cena de crime), como pela legislação.

\section{A gestão da cena de crime e a avaliação da base de dados de perfis de DNA}

O local onde ocorre um crime necessita da intervenção dos órgãos de polícia criminal (OPCs) para proceder a recolha de vestígios aí deixados. Por regra, os crimes de natureza sexual e os homicídios serão aqueles que exigem um

\footnotetext{
${ }^{6}$ A criminalística, ciência que tem por objetivo o reconhecimento de objetos extrínsecos relativos ao crime e à identidade do criminoso, é tradicionalmente descrita como a "ciência da individualização" (Kirk, 1963). A ciência forense distingue assim entre identificação e individualização. Enquanto individualização significa a possibilidade de se definir uma única fonte como sendo a origem de um vestígio de uma cena de crime, dentro de um leque de várias fontes possíveis, a identificação apenas permite estreitar a fonte potencial de origem a um grupo ou classe de objetos (Cole e Dioso-Villa, 2009: 3), na medida em que "é o processo de se estabelecer a identidade de um indivíduo sendo esta um conjunto de caracteres que o individualizam" (Pinheiro, 2008: 13). Uma nova epistemologia da identificação forense (Cole, 2009) reclama hoje que é impossível alcançar a individualização "perfeita", devendo-se falar de probabilidades e não de certezas (Saks e Koehler, 2005). No caso da genética forense o DNA apenas permite a identificação e não a individualização (Amorim, 2012).
} 
trabalho mais acurado por parte destas entidades, e nos quais o recurso à tecnologia de DNA pode ser mais necessário, não invalidando, porém, que outras técnicas de recolha de vestígios, como a recolha de impressões digitais, por exemplo, também tenham lugar.

A lei portuguesa estabelece que a primeira diligência a tomar pela polícia após conhecimento de um crime é comunicá-lo ao Ministério Público (artigo 248. ${ }^{\circ}$ do Código de Processo Penal - cf. Castelo e Pereira, 2007). ${ }^{7}$ Contudo, os OPCs, mesmo antes de receberem ordens da autoridade judiciária competente, podem proceder a atos necessários e urgentes para assegurar os meios de prova, assim como após a intervenção do Ministério Público podem desenvolver diligências para assegurar novos meios de prova de que venham a ter conhecimento (respetivamente, n. ${ }^{\circ} 1 \mathrm{e} \mathrm{n} .^{\circ} 3$ do artigo 249. ${ }^{\circ}$, cf. Castelo e Pereira, 2007).

Como está plasmado no artigo $7 .^{\circ}$ da Lei n. ${ }^{\circ} 49 / 2008$, os crimes que envolvem homicídios e agressões sexuais estão, por excelência, na alçada da Polícia Judiciária, coadjuvada pela Polícia Científica. À polícia técnica, em trabalho complementar com a PSP ou com a GNR, por seu turno, compete executar as diligências necessárias com vista à produção da prova material do crime, como por exemplo: inspeção do local, preservação dos vestígios encontrados, preservação do local do crime, salvaguardando e proibindo o acesso de estranhos ao local, realização de buscas, inquirição de testemunhas com vista a tentar compreender o que terá sucedido, e, em determinadas circunstâncias, recolha e transporte dos vestígios, bem como identificação do cenário do crime, quer através da descrição documental do cenário encontrado, quer ainda através da utilização de elementos áudio e vídeo como instrumentos auxiliares a incorporar no processo. Assim, a Polícia Científica, pela natureza própria das suas competências e dos instrumentos humanos, materiais, técnicos e científicos que tem ao seu dispor, assume uma posição de retaguarda, atuando numa fase em que outro órgão de investigação criminal procedeu já às primeiras diligências (4 a) e b) do artigo 3. ${ }^{\circ}$, Lei n. ${ }^{\circ}$ 49/2008).

Este articulado, porém, parte do pressuposto que todos os OPCs estão aptos a fazer uma intervenção célere e eficiente no local do crime, obedecendo não apenas ao princípio do imediatismo e da urgência dos atos (Braz, 2010: 36), mas também partindo do princípio de que a primeira entidade policial a ter conhecimento do crime deverá ser aquela a deslocar-se

\footnotetext{
7 Compete aos órgãos de polícia criminal, mesmo por iniciativa própria, colher notícia dos crimes e impedir quanto possível as suas consequências, descobrir os seus agentes e levar a cabo os atos necessários e urgentes destinados a assegurar os meios de prova.
} 
ao local e proceder às primeiras diligências com vista à preservação da cena do crime e aos primeiros atos cautelares, tão importantes para a futura investigação.

A fase inicial, denominada inspeção judiciária, pressupõe uma análise cuidadosa à cena de crime para recolher prova física e testemunhal. É uma etapa crucial e, acima de tudo, é também importante para poder planear estrategicamente a posterior intervenção e determinar a quem pertence a gestão da cena do crime. Na verdade, a existência de uma "hora de ouro" 8 associada ao crime de cenário reflete-se em todas as fases subsequentes da investigação criminal. Proveniente do trabalho desenvolvido pelas entidades policiais inglesas, como relatado por alguns dos nossos entrevistados, assenta na ideia de que as primeiras horas da investigação que sucedem à ocorrência de um crime são cruciais para a descoberta da verdade ou para obter a chave que resolve o enigma. Consequentemente, num cenário específico onde ocorreu um crime, quanto mais rápida for a intervenção policial, maiores são as probabilidades de o agente policial fazer uma descrição fiel do que ali encontra, tornando-se necessário intervir tão rapidamente quanto possível e preservar o mais possível o local, mantendo-o semelhante ao original no momento imediato que se seguiu ao ato criminoso.

O momento da inspeção judiciária, que antecede o momento de investigação criminal, de índole mais técnica e especializada, pode, assim, ser considerado a fase crucial para desvendar o "puzzle". Porém, talvez seja a fase mais vulnerável de todo o processo, já que o local do crime é também um local "complexo, precário e frágil” (Braz, 2010: 212) e de fácil destrutibilidade, estando sujeito à sua violabilidade por fatores externos (condições meteorológicas), fatores humanos (contaminação), intervenção metodológica incorreta, escassez de meios humanos e materiais adequados, entre outros.

De acordo com os entrevistados, parecem notórias as discrepâncias que separam, quer ao nível de recursos humanos, quer ao nível de especialização e formação que recebem, os diferentes OPCs, evidenciando ainda saberes e práticas distintas das polícias que intervêm na cena do crime. Como dizia um dos entrevistados, existem fragilidades na formação de elementos das outras polícias, que podem comprometer o sucesso da investigação criminal:

Alguns elementos das outras polícias não estão bem sensibilizados para aquilo que há a fazer. Portanto, até à chegada da Polícia Judiciária ao terreno o que acontece é que as outras polícias têm a obrigação de preservar o local. Já o fazem muito melhor

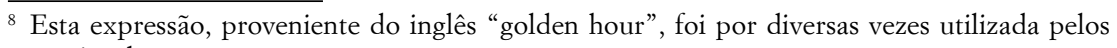
entrevistados. 
e muito mais do que há alguns anos atrás! Não há comparação possível! Mesmo assim, às vezes, talvez por alguma fragilidade na formação [...] apesar das boas vontades isso não é bem realizado [...]. E isso é uma das dificuldades que temos.

Como referido anteriormente, aos agentes policiais que chegam em primeiro lugar à cena de crime - geralmente a GNR ou a PSP - compete proceder às primeiras diligências, sendo auxiliados mais tarde por polícias especializadas. ${ }^{9}$ É a partir da informação que estes primeiros atores transmitem às restantes entidades que o crime pode ser tipificado e, consequentemente, e em função dessa tipificação, será decidido: A quem compete a gestão da cena do crime? Quem coordena as operações? Quem as dirige? Quem autoriza os atos a realizar? Que tipo de intervenção e instrumentos técnicos são necessários? Que agentes operacionais devem ser destacados para o local? Quem faz?

Segundo um dos entrevistados, as ambiguidades da lei e as próprias dificuldades de proceder no terreno a uma correta tipificação do crime, que permitiria decidir a quem compete a gestão da investigação, cria dificuldades de operacionalização do trabalho policial e, nas suas palavras, "[a]inda se consegue ver que muita coisa é inviabilizada por ter havido uma má gestão do local [do crime]”. O mesmo entrevistado acrescenta ainda que, por vezes, é difícil definir a quem compete recolher prova em determinado contexto.

[...] quando acontece um crime de cenário, qualquer coisa que tenha a ver com um espaço, que tem a ver com esse evento, o primeiro problema a resolver é saber quem é a entidade competente no plano policial para o abordar.

E salienta ainda os conflitos ${ }^{10}$ que essas zonas de incerteza colocam na prática de terreno: ${ }^{11}$

\footnotetext{
${ }^{9}$ Como consta do n. ${ }^{\circ} 4$ do artigo 171. ${ }^{\circ}$ do Código de Processo Penal: "Enquanto não estiver presente no local a autoridade judiciária ou o órgão de polícia criminal competentes, cabe a qualquer agente da autoridade tomar provisoriamente as providências referidas no $\mathrm{n}^{\circ}{ }^{2}$, se de outro modo houver perigo iminente para a obtenção da prova." (cf. Castelo e Pereira, 2007).

${ }^{10} \mathrm{O}$ artigo $9 .^{\circ}$ da Lei n. ${ }^{\circ} 49 / 2008$, de 27 de agosto refere que "[s]e dois ou mais órgãos de polícia criminal se considerarem incompetentes para a investigação criminal do mesmo crime o conflito é dirimido pela autoridade judiciária competente em cada fase do processo".

${ }^{11} \mathrm{O} \mathrm{n}^{\circ}{ }^{\circ} 4$ do artigo $2 .^{\circ}$ da Lei n. ${ }^{\circ}$ 49/2008, de 27 de agosto, estipula que "[o]s órgãos de polícia criminal atuam no processo sob a direção e na dependência funcional da autoridade judiciária competente, sem prejuízo da respectiva organização judiciária". Porém, o artigo $8 .^{\circ}$, n. $^{\circ} 1$ refere que o Procurador Geral da República pode deferir "[...] a investigação de um crime [...] a outro órgão de polícia criminal desde que tal se afigure, em concreto, mais adequado ao bom andamento da investigação e, designadamente, quando: [...] d) A investigação não exija especial mobilidade de atuação ou meios de elevada especialidade técnica $[\ldots]$ ”.
} 
Às vezes, há aqui algumas guerrilhas de competências [...] e às vezes não se aprofunda a razão das coisas e a perceção de porque é que no terreno [as forças policiais] falharam [...] Por exemplo, a questão dos furtos de veículos: aí, inequivocamente, a competência deve ser da GNR, mas, muitas vezes, o veículo transforma-se num processo de competência da $\mathrm{PJ}[\ldots]$ quando está em causa o tráfico e a viciação de veículos [...] Os crimes que acontecem [que são da competência da PJ] não aparecem certinho com um rótulo... ${ }^{12}$

Um fator que pode criar contingências adicionais ao trabalho de investigação criminal prende-se, precisamente, com o facto de, num primeiro momento, nem sempre ser possível identificar o tipo de crime em causa.

A esta realidade acrescenta este ator que, na sua opinião, as "outras polícias" não têm formação técnica especializada nem meios materiais para acondicionar o material recolhido em cena de crime ou, mesmo tendo, muitas vezes fazem um uso errado desse mesmo material.

[...] a regra do bom acondicionamento prevê hoje um conjunto de sacos de prova para cada um dos objetos adequados à sua natureza e à sua dimensão, que obedecem a dois princípios [...]: primeiro, o que é vivo, embrulha-se [...] em saco de papel, o que é volátil recolhe-se em saco hermético. Às vezes, na prática, confrontamo-nos com coisas exatamente ao contrário!

De salientar, ainda, uma outra questão de grande importância, que nos remete para o tipo de atitude a manter pelos "outros" OPCs que intervêm na inspeção judiciária. Esta entrada no terreno poderá ser de índole mais dinâmica ou mais estática, ficando ao arbítrio de quem se encontra efetivamente no terreno tomar essa decisão.

Uma atitude dinâmica pelos OPCs que auxiliam na investigação do crime pressupõe que se limitem a proceder aos atos cautelares estritamente necessários, de forma a manter a originalidade do cenário encontrado, sendo este posicionamento válido também para os elementos da PJ que se deslocam ao cenário de crime, enquanto aguardam por agentes com competências técnicas mais específicas. Porém, o simples facto de terem que providenciar às primeiras diligências contempladas na lei, por si só, e atendendo aos constrangimentos ao nível de formação e de recursos técnicos e humanos disponíveis, pode conduzir a diligências mal realizadas. Assim, uma das formas de minimizar esses potenciais erros seria adotar uma posição estática:

${ }_{12} \mathrm{O}$ artigo $7^{\circ}$, da Lei n. ${ }^{\circ}$ 49/2008 relativo à Competência da Polícia Judiciária em matéria de investigação criminal enumera os crimes que deverão estar sob a sua alçada. 
A primeira coisa a fazer no local do crime [é] meter as mãos nos bolsos! Porque todos nós temos uma tendência para mexer, para ver e, portanto, a primeira atitude [é] ver com os olhos, ter essa abordagem inicial global, perceber o que é que está ali em causa $[\ldots]$.

Assim, e segundo o entrevistado, se uma atitude estática pressupõe a salvaguarda imediata dos vestígios para não correr o risco de danificar ou deteriorar vestígios importantes, geralmente ao cuidado dos "outros" órgãos de polícia criminal (GNR ou PSP), a verdade é que em consequência isso poderá levar a que vestígios que devem ser recolhidos no imediato se possam perder. Deste modo, agentes com pouca formação, ao optarem por uma atitude dinâmica, estarão a cumprir a sua função de salvaguardar a cena do crime e os vestígios aí deixados. Porém, sendo esta intervenção feita por agentes que, geralmente, não possuem nem as qualificações adequadas a um bom desempenho, nem os recursos necessários a uma boa recolha, podem acabar por estragar irremediavelmente as provas deixadas pelo criminoso.

Estes agentes de proximidade, ao chegarem ao local, conscientes de que a competência de atuação não lhes pertence e que devem esperar a entrada no terreno de pessoal e meios qualificados, podem estar a contribuir para que vestígios relevantes possam ser danificados por terceiros, por não serem recolhidos em tempo útil, remetendo-nos para a hora de ouro que todos os crimes de cenário compreendem. Como refere um dos entrevistados, a relevância de agir em tempo útil prende-se não só com a necessidade de os vestígios serem recolhidos da forma mais célere possível, evitando contaminações subsequentes, como ainda garantir que todos os vestígios importantes são recolhidos naquele momento, evitando ter que voltar ao local para fazer novas colheitas, em que o cenário já não se encontrará, provavelmente, nas mesmas condições.

[...] os ingleses chamam-lhe, precisamente, a "golden hour", a necessidade de trabalhar logo que se dá o crime no sentido de não só recolher os vestígios como chegar ao autor, porque pode pôr-se em fuga, etc., etc., e, portanto, nós trabalhamos ... quando se dá um crime ... a 300 ... não é a 200! É a 300 ou 400 à hora! Nessas circunstâncias, como é natural, um erro pode ocorrer por não nos termos lembrado deste ou daquele aspeto. Aqui cabe à gestão da equipa assumir o erro, naturalmente, não é?

Porém, adotando uma atitude ou outra, na verdade, o risco está sempre presente. Por conseguinte, uma forma de o minimizar é registar pormenorizadamente todos os passos dados pelos elementos que abordam a cena do crime, isto é, "assinalar na avaliação do local [...] os percursos de entrada 
e os percursos de saída, porque nós [polícias/técnicos] ao entrar também fazemos pegadas". Esta situação torna-se uma das contingências do local do crime, a qual é praticamente impossível de evitar, exceto se o operacional se apresentasse, como refere um dos entrevistados, como "um boneco com uma cana de pesca", transmitindo a ideia de que só entrando na cena do crime suspenso minimizaria as possibilidades dos próprios técnicos contaminarem à sua passagem o local, nomeadamente pelas pegadas deixadas.

[...] não há uma cana de pesca, mas ele [polícia] ${ }^{13}$ tem de chegar primeiro de forma a pôr em causa o mínimo possível o espaço que vai observar. Mas se ele tiver que passar por um sítio onde para entrar tem que se encostar a uma porta ou abrir qualquer divisória, o que ele tem depois é que registar que fez aquilo! O que ele tem que dizer é que aquela porta está mudada porque foi resultante da minha entrada e não foi resultante da fuga do bandido ou da entrada do indivíduo.

Outro obstáculo ao sucesso de uma investigação criminal bem-sucedida prende-se com o carácter restritivo da legislação que regula a criação e funcionamento da base de dados de perfis de DNA em Portugal. Como nos disse um dos nossos entrevistados, a lei foi sobretudo uma solução política, com vista a não criar conflitos entre diferentes interesses (dos peritos forenses, da polícia e dos defensores de direitos humanos) e aponta como uma das maiores fragilidades o facto da inserção de um perfil estar dependente da decisão do juiz:

Ouço queixas de todos os lados [...] Enfim, a lei é uma má lei [...] não pode deixar na mão do juiz o mandar inserir o perfil, não pode! Devia ser automático [...] a solução encontrada é uma solução salomónica, para não criar atritos.

Outro entrevistado refere-se às limitações criadas pelo carácter restritivo da base de dados de perfis de DNA, nomeadamente o facto de ser obrigatória a eliminação do perfil no termo do processo-crime ou no fim do prazo máximo de prescrição do procedimento criminal previsto no Código Penal:

Acho que existe esse excesso de garantismo que põe ali algumas questões, porventura, deslocadas. Como, por exemplo, a questão da permanência dos perfis [...] o registo

${ }_{13}$ Este entrevistado, ao referir-se ao polícia engloba aqui qualquer um dos operacionais que abordam a cena do crime, seja da PJ, GNR, PSP, ou mesmo os técnicos do Laboratório de Polícia Científica (LPC) ou da Unidade de Polícia Técnica (UPT) da PSP que se deslocam ao local. Será, digamos assim, uma regra que todos deveriam cumprir com o máximo rigor. 
criminal hoje tem uma vida muito curta! Se nós tivéssemos nas [bases de dados de] impressões digitais regras dessas, as nossas bases [da PJ] eram praticamente ineficazes também!

A perspetiva da necessidade da eficácia da base de dados de perfis de DNA é também acentuada no seguinte extrato, quando o entrevistado defende que os perfis de DNA não deviam sair da base de dados e critica a necessidade de intervenção do juiz para serem comunicados dados aos órgãos de investigação criminal:

Os perfis deviam manter-se indefinidamente [na base de dados de perfis de DNA]. Mas a lei traduz uma vontade política e já acho um milagre finalmente termos uma lei [da base de dados de perfis de DNA]. Mas a eficácia da base de dados vai ser muito reduzida com o artigo $19^{\circ}{ }^{14}[\ldots]$ Vai ser a total burocracia.

Os entrevistados criticaram enfaticamente a ineficácia da base de dados de perfis de DNA por impossibilitar a concretização de uma utilização retrospetiva da informação, que poderia ser obtida pela retenção de perfis que permitissem uma base comparativa com material biológico colhido em cena de crime:

Uma micro-base de dados, uma pseudo-base de dados que, no fundo, não me vai trazer mais do que saber que os indivíduos que lá estão foram criminosos [...] O que eu queria mesmo era uma base de dados construída de tal forma que, perante um vestígio biológico encontrado no local do crime, [permitisse] saber quem ele é.

Estes discursos ilustram claramente as tensões locais criadas por uma legislação que, por um lado, se enquadra numa cultura jurídica que subordina o papel da polícia à autoridade judiciária e que, por outro lado, reverteu a lógica do funcionamento da base de dados de perfis de DNA a favor do poder da ciência forense. Como referia um dos nossos entrevistados:

A utilização do DNA na investigação criminal tem estado subordinada aos interesses da investigação científica. Sem retirar o mérito à investigação, diria que é um processo demasiado moroso e orientado mais para a descoberta científica. Essas lógicas não

\footnotetext{
${ }^{14}$ O número 1 do artigo $19{ }^{\circ}$ da Lei n..$^{\circ}$ /2008, referido pelo entrevistado, estabelece o seguinte: a) Os dados são comunicados pelo INML ao juiz competente consoante o tipo ou fase do processo, mediante requerimento fundamentado; $b$ ) $\mathrm{O}$ juiz referido na alínea anterior comunica os dados em questão, quando necessário ou mediante requerimento fundamentado, ao Ministério Público ou aos órgãos de polícia criminal, proferindo para o efeito despacho fundamentado.
} 
servem os interesses da polícia e da investigação criminal: temos que ter respostas em tempo útil.

Um dos pressupostos fundamentais do sucesso de uma base de dados de perfis de DNA para investigação criminal é a expansão da quantidade de informação, tornado possível pelo alargamento de critérios de inserção de perfis e pela não remoção dos mesmos (McCartney, 2006: 55-57). O suspeito genético de que falámos anteriormente deriva do uso retrospectivo da informação genética e afigura-se como um pilar da biolegalidade e do imaginário forense. À luz destas entrevistas, pode-se afirmar que os elementos principais que a mensagem política da eficácia e infalibilidade da tecnologia do DNA apresenta quanto à identificação de criminosos e ao combate e prevenção da criminalidade parece estar comprometida.

\section{Conclusão}

Os modelos de trabalho policial de investigação criminal e de utilização da tecnologia de DNA na identificação individual que são dominantes no imaginário coletivo - tanto no discurso dos governos, como nas mensagens culturais circuladas pelos meios de comunicação social - reproduzem, com maior ou menor veracidade, as práticas de investigação criminal de países como Inglaterra ou EUA, que se apoiam nos seguintes elementos: (1) existência de bases de dados de DNA muito extensivas e amplos poderes conferidos à polícia no que diz respeito à recolha e análise de informação genética; (2) recursos materiais e científicos que providenciam os artefactos materiais e as orientações técnicas para a recolha de material de cena de crime, de acordo com procedimentos científicos que não comprometam a cadeia de custódia; (3) culturas organizacionais que estabelecem com clareza os princípios, rotinas e acções práticas em relação aos procedimentos de investigação criminal, pelos quais serão produzidos artefactos materiais destinados ao trabalho laboratorial e resultados de análise científica sujeitos a escrutínio e auditoria pelos pares (Williams e Johnson, 2008: 6-7).

As entrevistas realizadas revelam o posicionamento da Polícia Judiciária na rede sociotécnica formada pelos usos da tecnologia de DNA na investigação criminal. Os resultados obtidos mostram como essa rede envolve elementos heterogéneos, atores sociais que ocupam distintas posições em relações sociais de poder e de legitimação social de saberes periciais. A subordinação simbólica do direito à ciência forense, que parece caracterizar a cultura regulatória da sociedade portuguesa (Santos, 2002), por um lado, e a subordinação hierárquica e operacional da polícia à autoridade judiciária coadjuvada pela ciência forense, por outro, vêm defrontar atores 
investidos de diferentes capacidades reconhecidas de utilizar a informação genética na investigação criminal (Machado, 2011).

Tal como em Costa (2003) se havia concluído existirem tensões entre um trabalho laboratorial de análise de materiais recolhidos em cena de crime orientado pela tentativa de aproximação à harmonização de procedimentos internacionais da ciência forense e especificidades locais produzidas pelo ordenamento jurídico português, também a investigação criminal apoiada na tecnologia de DNA parece ilustrar cabalmente a heterogeneidade de modalidades de incorporação de ciência e tecnologia derivadas de especificidades nacionais e locais. As contingências associadas à investigação criminal em Portugal revelam uma articulação complexa entre saberes e práticas, particularidades da legislação que regula não só a organização do trabalho policial como a criação e utilização de uma base de dados de perfis de DNA para identificação criminal, que indiciam uma aposta na globalização e harmonização de procedimentos, apoiados nas experiências de outros países, porém assentes numa cultura jurídica, profissional e criminológica com especificidades e particularidades de carácter nacional e local.

Em síntese, a realidade da investigação criminal em Portugal parece afastar-se dos modelos de biolegalidade e de imaginário forense projetados por países que conheceram já uma ampla utilização da tecnologia de DNA na investigação criminal, devido a três ordens de factores: (1) falta de formação técnico-científica da PSP e da GNR e de recursos materiais para uma adequada recolha de vestígios de cena de crime da parte destas forças policiais; (2) ambiguidade da lei e sua difícil aplicação prática no que toca à definição clara de competências de investigação criminal; (3) restrições legais ao uso e acesso de informação armazenada na base de dados de perfis de DNA tutelada pelo Instituto Nacional de Medicina Legal e falta de operacionalidade desse tipo de instrumento de apoio à investigação criminal.

Além dos factores enunciados, que explicam a discrepância entre a realidade portuguesa e o modelo de biolegalidade e de imaginário forense que provêm de países que utilizam já há várias décadas, de modo rotineiro, a tecnologia de DNA, existem diferenças consideráveis em termos de funcionamento dos tribunais. A incorporação da tecnologia de DNA nas práticas de investigação criminal é originária de um sistema de justiça adversarial, como o americano ou inglês, enquanto o sistema de justiça português assenta num regime inquisitorial. Num regime adversarial, o julgamento é ocasião de confronto entre os representantes do Estado e dos acusados, sendo as provas susceptíveis de desconstrução pública na sua apresentação e discussão em tribunal. Tal permite avaliar a robustez dos elementos de prova apresentados ou, pelo contrário, as debilidades das provas, as incertezas produzidas pela técnica ou, 
ainda, a possibilidade de quebras na cadeia de custódia. Assim, o processo adversarial pode caracterizar-se pela tentativa de descredibilização das provas submetidas pela outra parte e pelo triunfo de uma das versões apresentadas perante o tribunal e o júri (Cooper, 2004). É precisamente o "regime de ceticismo" orientado para a desconstrução da prova científica, que se verifica no sistema adversarial (Toom, 2010: 176), que permite colocar em confronto a defesa e a acusação ou mesmo o discurso do(s) peritos (Jasanoff, 2006). O papel do juiz no processo adversarial é o de um árbitro passivo e imparcial, ao qual compete definir as regras do julgamento e a admissibilidade das provas apresentadas. O juiz não conduz o inquérito, nem determina diligências para recolha de prova, sendo as partes litigantes autónomas na arguição do conflito em torno de distintas versões dos factos.

Já em ordenamentos jurídicos de carácter inquisitorial, como é o caso português e, de modo geral, da maioria dos países da Europa Ocidental, o juiz desempenha um papel ativo enquanto "averiguador dos factos", sendo as decisões jurídicas assentes no inquérito judicial e na procura da "verdade". Em países como Portugal, o Ministério Público detém o ónus da prova e, não obstante a defesa poder requerer contraprova e perícias adicionais, estas têm que ser admitidas pelo juiz. Estas características do sistema de justiça português fazem com que a prática de admissão de contraprova nos tribunais portugueses seja escassa (Costa, 2003; Costa et al., 2003), o que pode criar duas consequências distintas: a reduzida presença de prova de DNA nos julgamentos em Portugal (Machado e Prainsack, 2012: cap. 3) ou, ainda, a criação de um cenário favorável à perceção desta tecnologia como uma "máquina da verdade" (Lynch et al., 2008) que não encontra contestação em virtude dos constrangimentos na admissão e apreciação de contraprova já descritos.

Por fim, é de referir que as representações populares da investigação criminal e do sistema de justiça assentam, com frequência, numa comparação entre casos reais e o imaginário projetado pelas representações ficcionais da polícia em que o recurso a tecnologia sofisticada, métodos científicos e deduções brilhantes é capaz de resolver os casos mais complexos, rapidamente e sem erro (Machado e Santos, 2012). Ora, como referimos, as narrativas das séries ficcionais sobre investigação criminal, nomeadamente da série televisiva Crime Scene Investigation (CSI), poderão elaborar crenças desproporcionadas acerca da eficácia do trabalho de investigação criminal apoiado em tecnologias de identificação por DNA. Neste sentido, a criação de expectativas desajustadas da realidade pode causar, junto da opinião pública em Portugal, um acréscimo de avaliações negativas sobre a atuação da polícia portuguesa e deste modo fragilizar a confiança pública no sistema de justiça criminal 
(Machado e Santos, 2012). De facto, a ocorrência de casos criminais reais amplamente mediatizados em Portugal e não resolvidos - de que é exemplo revelador o caso do desaparecimento de Madeleine McCann - pode reforçar imagens de ineficiência da polícia portuguesa que, de resto, são coincidentes com representações negativas do sistema de justiça em Portugal, encarado como moroso, ineficiente e discriminatório.

\section{Referências bibliográficas}

Aas, Katja (2006), “The Body Does Not Lie': Identity, Risk and Trust in Technoculture”, Crime, media and culture, 2(2), 143-158.

Akrich, Madeleine; Nunes João; Paterson, Florence; Rabehariso, Vololona (orgs.) (2008), The Dynamics of Patient Organizations in Europe. Paris: Presses de l' École des Mines.

Amorim, António (2012), "Opening the DNA Black Box: Demythologizing Forensic Genetics", New Genetics and Society, 31(3), 259-270.

Atkinson, Paul; Glasner, Peter; Greenslade, Helen (orgs.) (2007), New Genetics, New Identities. London: Routledge.

Braz, José (2010), Investigação criminal. A organização, o método e a prova. Os desafios da nova criminalidade. Coimbra: Almedina [2., ed.].

Callon, Michel (1987), "Society in the Making: The Study of Technology as a Tool for Sociological Analysis", in Wiebe Bijker; Thomas P. Hugues e Trevor Pinch (orgs.), The Social Construction of Technical Systems: New Directions in the Sociology and History of Technology. London: MIT Press, 83-103.

Caplan, Jane; Torpey, John (orgs.) (2001), Documenting Individual Identity: The Development of State Practices in the Modern World. Princeton: Princeton University Press.

Castelo, Tiago; Pereira,Joel (2007), Código do Processo Penal. Compilações Legislativas. Versão 1.3. Edição Verbo Jurídico. Página consultada a 2 de abril de 2013, http://www.verbojuridico.com/download/cpp2007_v1.3.pdf.

Clarke, Adele E.; Shim, Janet; Shostak, Sara; Nelson, Alondra (2009), "Biomedicalising Genetic Health, Diseases and Identities", in Paul Atkinson; Peter Glasner e Margaret Lock (orgs.), Handbook of Genetics and Society. Mapping the New Genomic Era. London \& New York: Routledge, 21-40.

Cole, Simon (2002), Suspect Identities: A History of Fingerprinting and Criminal Identification. Harvard: Harvard University Press.

Cole, Simon (2009), "Forensics Without Uniqueness, Conclusions without Individualization: The New Epistemology of Forensic Identification", Law, Probability and Risk, 8 (3), 233-255.

Cole, Simon; Dioso-Villa, Rachel (2007), "CSI and its Effects: Media, Juries, and the Burden of Proof”, New England Law Review, 41(3), 435-470. 
Cole, Simon; Dioso-Villa, Rachel (2009), “Investigating the 'CSI Effect' Effect: Media and Litigation Crisis in Criminal Law", Stanford Law Review, 61(6), 1335-1374.

Cole, Simon; Lynch, Michael (2006), "The Social and Legal Construction of Suspects”, Annual Review of Law and Social Science, 2, 39-60.

Cooper, Susan (2004), "Truth and Justice, Inquiry and Advocacy, Science and Law”, Ratio Juris, 17(1), 15-26.

Costa, Susana (2003), A justiça em laboratório. A identificação por perfis genéticos de ADN. Entre a harmonização transnacional e a apropriação local. Coimbra: Almedina.

Costa, Susana; Machado, Helena; Nunes, João Arriscado (2003), "O ADN e a justiça: A biologia forense e o direito como mediadores entre a ciência e os cidadãos”, in Maria Eduarda Gonçalves (org.), Os portugueses e a ciência. Lisboa: Dom Quixote, 199-233.

Deutsch, Sarah K.; Cavender, Gray (2008), “CSI and Forensic Realism”, Journal of Criminal Justice and Popular Culture, 15(1), 34-53.

Durnal, Evan W. (2010), “Crime Scene Investigation (As Seen on TV)”, Forensic Science International. DOI: 10.1016/j.forsciint.2010.02.015.

Garland, David (2001), The Culture of Crime Control. Oxford: Oxford University Press.

Gibbon, Sarah; Novas, Carlos (orgs.) (2008), Biosocialities, Genetics and the Social Sciences: Making Biologies and Identities. London: Routledge.

Hindmarsh, Richards; Prainsack, Barbara (orgs.) (2010), Genetic Suspects: Global Governance of DNA Profiling and Databasing. Cambridge: Cambridge University Press.

Jasanoff, Sheila (org.) (2004), States of Knowledge. The Co-Production of Science and the Social Order. London: Routledge.

Jasanoff, Sheila (2006), “Just Evidence: The Limits of Science in the Legal Process”, Journal of Law, Medicine and Ethics, 34(2), 328-341.

Kirk, P.L. (1963), “The Ontogeny of Criminalistics”, Journal of Criminal Law, Criminology and Police Science, 54, 235-238.

Kruse, Corinna (2010), "Producing Absolute Truth: CSI Science as Wishful Thinking”, American Anthropologist, 112(1), 79-91.

Latour, Bruno (1987), Science in Action. Cambridge: Harvard University Press.

Lazer, David (org.) (2004), The Technology of Justice: DNA and the Criminal Justice System. Cambridge, MA: MIT Press.

Lei n. ${ }^{\circ}$ 5/2008 de 12 de fevereiro, "Aprova a criação de uma base de dados de perfis de ADN para fins de identificação civil e criminal”. Diário da República, 1. a série - N. 30. Página consultada no Diário da República Eletrónico a 02.04.2013, em http://dre. pt/pdf1sdip/2008/02/03000/0096200968.pdf.

Lei n. ${ }^{\circ}$ 49/2008 de 27 agosto, "Aprova a Lei de Organização da Investigação Criminal”. Diário da República, 1. ${ }^{\text {a }}$ série - N. ${ }^{\circ} 165$. Página consultada no Diário da República Eletrónico a 20.10.2012, em http://dre.pt/pdf1sdip/2008/08/16500/060380 6042.pdf. 
Lei n. ${ }^{\circ}$ 45/2004 de 19 de agosto, "Estabelece o regime jurídico das perícias médico-legais e forenses”. Diário da República, 1. a série - N. ${ }^{\circ}$ 195. Página consultada no Diário da República Eletrónico a 02.04.2013, em http://dre.pt/pdf1s/2004/08/ 195A00/53625368.pdf.

Lynch, Michael; Mcnally, Ruth (2009), "Forensic DNA Databases and Biolegality: The Coproduction of Law, Surveillance Technology and Suspect Bodies", in Paul Atkinson; Peter Gaslen e Margaret Lock (orgs.), The Handbook of Genetics and Society. Mapping the New Genomic Era. London \& New York: Routledge, 283-301.

Lynch, Michael; Cole, Simon A.; McNally, Ruth; Jordan, Kathleen (2008), Truth Machine. The Contentious History of DNA Fingerprinting. Chicago/London: University of Chicago Press.

Lyon, David (2001), Surveillance Society: Monitoring Everyday Life. Buckingham: Open University Press.

Machado, Helena (2011), "Construtores da bio(in)segurança na base de dados de perfis de ADN”, Etnográfica, 15(1), 153-166.

Machado, Helena; Prainsack, Barbara (2012), Tracing Technologies. Prisoners' views in the Era of CSI, Aldershot, Hampshire: Ashgate Publishing.

Machado, Helena; Santos, Filipe (2009a), “The disappearance of Madeleine McCann: Public Drama and Trial by Media in the Portuguese Press", Crime, Media, Culture, 5(2), 146-167.

Machado, Helena; Santos, Filipe (2009b), "Popular Press and Forensic Genetics in Portugal - Expectation and Disappointment Regarding Two Cases of Missing Children", Public Understanding of Science, 20(3), 303-318.

Machado, Helena; Santos, Filipe (2012), "Entre a polícia ficcional e a polícia real: Os usos do DNA na investigação criminal em Portugal”, in Susana Durão (org.), Polícia, segurança e ordem pública. Perspetivas Portuguesas e Brasileiras. Imprensa de Ciências Sociais: Lisboa, 154-165.

Machado, Helena; Silva, Susana; Amorim, António (2010), "Políticas de identidade: Perfil de DNA e a identidade genético-criminal”, Análise Social, XVL(196), 537-553.

Machado, Helena; Moniz, Helena; Santos, Filipe; Silva, Susana (2011a), Análise comparativa de legislação que regula o funcionamento de bases de dados de perfis de DNA com fins forenses na Europa. Coimbra: Centro de Estudos Sociais. Consultado a 02.04.2013, em http://dnadatabase.ces.uc.pt/list_documents.php.

Machado, Helena; Santos, Filipe; Silva, Susana (2011b), "Prisoners' Expectations of the National Forensic DNA Database: Surveillance and Reconfiguration of Individual Rights", Forensic Science International, 210(1-3), 139-143. DOI:10.1016/j.forsciint.2011.02.020.

McCartney, Carole (2006), Forensic Identification and Criminal Justice: Forensic Science, Justice and Risk. Willan Publishing: Cullompton. 
Nuffield Council on Bioethics (2007), The Forensic Use of Bioinformation: Ethical Issues. London: Nuffield Council on Bioethics.

Pinheiro, Maria de Fátima (2008), "A perícia em genética e biologia forense - criminalística biológica”, in Maria de Fátima Pinheiro (org.), CSI Criminal. Porto: Universidade Fernando Pessoa, 11- 40.

Prainsack, Barbara; Kitzberger, Martin (2009), "DNA Behind Bars: Other Ways of Knowing Forensic DNA Technologies”, Social Studies of Science, 39(1), 51-79.

Rabinow, Paul (2008), “Afterword: Concept Work”, in Sarah Gibbon e Carlos Novas (orgs.), Biosocialities, Genetics and the Social Sciences: Making Biologies and Identities. London: Routledge, 188-192.

Rose, Nicolas (2007), Politics of Life Itself. Biomedicine, Power and Subjectivity in the Twenty-first Century. Oxfordshire: Princeton University Press.

Saks, Michael; Koehler, Jonathan (2005), "The Coming Paradigm Shift in Forensic Identification Science”, Science, 309(5736), 892-895.

Santos, Boaventura de Sousa (2002), Toward a New Legal Common Sense. Law, Globalization, and Emancipation. Londres: Butterworths.

Toom, Victor (2010), "Inquisitorial Forensic DNA Profiling in the Netherlands and the Expansion of the Forensic Genetic Body", in Richard Hindmarsh e Barbara Prainsack (orgs.), Genetic Suspects: Global Governance of DNA Profiling and Databasing. Cambridge: Cambridge University Press, 175-196.

Williams, Robin (2003), "Residual Categories and Disciplinary Knowledge: Personal Identity in Sociological and Forensic Investigations”, Symbolic Interaction, 26(4), 515-529.

Williams, Robin (2010), "DNA Databases and the Forensic Imaginary", in Richard Hindmarsh e Barbara Prainsack (orgs.), Genetic Suspects: Global Governance of DNA Profiling and Databasing. Cambridge: Cambridge University Press, 131-152.

Williams, Robin; Johnson, Paul (2008), Genetic Policing: The Use of DNA in Criminal Investigations. Devon/Portland: Willan Publishing.

Williams, Robin; Johnson, Paul; Martin, Paul (2004), Genetic Information and Crime Investigation. Social, Ethical and Public Policy Aspects of the Establishment, Expansion and Police Use of the National DNA Database. Durham: Durham University, School of Applied Social Sciences. 
